ISSN 1392-3196 / e-ISSN 2335-8947

Zemdirbyste-Agriculture, vol. 108, No. 2 (2021), p. 173-180

DOI 10.13080/z-a.2021.108.023

\title{
Pathogenicity of Colletotrichum acutatum to different strawberry cultivars and anthracnose control with essential oils
}

\author{
Armina MORKELIŪNĖ, Neringa RASIUKEVIČIŪTĖ, Alma VALIUŠKAITE் \\ Lithuanian Research Centre for Agriculture and Forestry \\ Kauno 30, Babtai, Kaunas distr., Lithuania \\ E-mail: armina.morkeliune@lammc.lt
}

\begin{abstract}
Colletotrichum spp. is a significant strawberry (Fragaria $\times$ ananassa Duch.) pathogen causing yield losses of up to $80 \%$. Due to the changing agrometeorological conditions, pathogens are able to spread in cooler climate countries. Essential oils (EO), as one of the environmentally friendly plant protection products, can be used to control plant pathogens. They possess antibacterial and antifungal properties. Because of the low toxicity and biodegradability, EO can be used in plant protection against pathogens instead of chemical products.

This study aimed to determine the pathogenicity of strawberry $C$. acutatum and evaluate five essential oils at different concentrations as potential bio-fungicides against strawberry anthracnose (Colletotrichum acutatum). The $C$. acutatum pathogenicity was evaluated on detached strawberry leaves. The inhibitory effect of five EO at $200,400,600,800$ and $1000 \mu \mathrm{L}^{-1}$ was evaluated in vitro, and at 800 and $1000 \mu 1 \mathrm{~L}^{-1}-$ on detached strawberry leaves. The cultivar 'Deluxe' was found to be the most susceptible to strawberry anthracnose, while 'Rumba' and 'Elegance' exhibited resistance. The results of Mentha piperita EO revealed its antifungal activity against $C$. acutatum. Meanwhile, Salvia officinalis EO had no influence. The Coriandrum sativum and Hyssopus officinalis EO slightly inhibited C. acutatum growth. The results of Thymus vulgaris EO assay in vitro demonstrated that it could be an effective biocontrol agent against strawberry anthracnose.

EO inhibited the mycelial growth of $C$. acutatum in vitro; however, the results of the assay on detached strawberry leaves showed that the efficacy of EO was not sufficient and needed further research.
\end{abstract}

Key words: antifungal activity, common sage, common thyme, coriander, hyssop, peppermint.

\section{Introduction}

The extreme temperature changes favour the spread of plant diseases and evolution of new strains. New or invasive species with possible higher dispersal capability could quickly adapt to variable conditions (Freeman et al., 2001; Aguado et al., 2014). Due to the agrometeorological conditions, pathogenicity, diversity and taxonomy of Colletotrichum species complex change the distribution of the pathogen and disease severity across the growing areas (Freeman et al., 2001; AvilaQuezada et al., 2018).

The Colletotrichum species complex infects and causes diseases on many economically important crops. Colletotrichum spp. causes fruit and crown rots, infections of stolons, petioles and leaves by C. acutatum, C. fragariae and C. gloeosporioides (Debode et al., 2015; Wagner, Hetman, 2016). The Colletotrichum spp. is dangerous to fruit plants and propagation material in nurseries, as it infects not only young or senescent tissues but also the whole plant at all growth stages (Peres et al., 2005; Wagner, Hetman, 2016). Warm temperatures promote the incidence of the pathogen and its severity during the growing season (Miller-Butler et al., 2019). The favourable conditions for fungus development are $25^{\circ} \mathrm{C}$ up to $40^{\circ} \mathrm{C}$ temperature and high humidity (Peres et al., 2005; Moral et al., 2012). C. acutatum can survive in the soil or on its surface in Nordic conditions (Parikka et al., 2016). The yield losses depend on the resistance of strawberry (Fragaria $\times$ ananassa Duch.) cultivars to Colletotrichum spp. (Wagner, Hetman, 2016); however, it can cause up to $80 \%$ of plant death in nurseries and more than 50\% yield losses (Sreenivasaprasad, Talhinhas, 2005).

Screening of Colletotrichum spp. pathogenicity on the detached strawberry leaves helps assess symptom development and reduce the overall time (MillerButler et al., 2018). Information about strawberry pathogenicity helps choose cultivars and design effective disease management systems (Freeman et al., 2001; MacKenzie et al., 2009; Wagner, Hetman, 2016; Miller-Butler et al., 2018).

Please use the following format when citing the article:

Morkeliūnė A., Rasiukevičiūtė N., Valiuškaitė A. 2021. Pathogenicity of Colletotrichum acutatum to different strawberry cultivars and anthracnose control with essential oils. Zemdirbyste-Agriculture, 108 (2): 173-180. DOI 10.13080/z-a.2021.108.023 
Growing of strawberry cultivars resistant to the Colletotrichum spp. is more environmentally friendly and cost-effective than chemical control (Wagner, Hetman, 2016). However, overuse of fungicides could lead to pathogen resistance (Miller-Butler et al., 2019). The control of Colletotrichum spp. is based on several strategies, including chemical and biological control, resistant cultivars, etc. (Aguado et al., 2014).

Natural plant protection agents that have a less adverse effect on crops such as plant extracts and essential oils showed a different level of antimicrobial efficacy to various ranges of fungal and bacterial pathogens. The essential oils (EO) and extracts can be applied as one of the eco-friendly plant protection products controlling plant pathogens or as plant defence inducers (Çetin et al., 2011; Aguado et al., 2014; Aćimović et al., 2016; Bajpai et al., 2019). Research studies have found that antibacterial and antifungal properties, biodegradability and low toxicity of EO make them a potential source of natural plant protection (Çetin et al., 2011; Aćimović et al., 2016). The EO include terpenes, esters, aldehydes and phenols are a source of natural antioxidants and biologically active compounds. EO mostly are secondary metabolites, which play an essential role in plant defence, as they often possess antimicrobial properties and are non-toxic and biodegradable (Girish, Fathima, 2019). As products from plants, EO have a wide application in pharmacy, fragrance and food industries; however, recent EO studies revealed their potential antimicrobial activity (Starović et al., 2016; Kumar, Kudachikar, 2018).

It has been reported in the literature, that thyme, coriander and peppermint EO had antifungal activity against plant diseases, including Colletotrichum spp. (Çetin et al., 2011; Duduk et al., 2015; Aćimović et al., 2016; Kumar, Kudachikar, 2018). The antifungal effect of Coriandrum sativum EO on the growth rate of Colletotrichum pathogens has been highlighted (Aćimović et al., 2016). C. sativum EO has antimicrobial activity against various plant and human pathogens (Laribi et al., 2015) as Aspergillus spp. and Fusarium spp. (Singh et al., 2006). The Salvia officinalis is rich in essential oils, flavonoids, phenolic and terpenoid compounds (Yilar et al., 2018). S. officinalis EO affects Fusarium spp. growth (Starović et al., 2016). Mentha piperita EO shows significant antifungal activity against Alternaria alternaria, Fusarium tabacinum, F. oxysporum and other pathogens (Desam et al., 2017). According to Cetin et al. (2011), T. sipyleus subsp. sipyleus var. rosulans and Origanum acutidens EO can be used as a natural preservative in food against casual agents of foodborne diseases like Escherichia coli, Pseudomonas spp., Geotrichum candidum and others. However, there is a lack of literature on the antifungal activity of Hyssopus officinalis EO. Some of the EO have been evaluated for controlling Colletotrichum spp. (Mandal, Mandal, 2015; Aćimović et al., 2016). However, there is a lack of investigations on the effects of $T$. vulgaris, M. piperita, $S$. officinalis and $H$. officinalis EO on strawberry Colletotrichum spp.

Due to the increasing cultivation area of new strawberry cultivars from warmer climate zones and growing disease incidence, it is essential to evaluate the susceptibility of various strawberry cultivars to Colletotrichum spp. Alternative products for biological plant protection are under investigation due to the increasing resistance of pathogens and the harm of pesticides to humans and the environment. As EO have antifungal properties, they could be one of the environment-friendly plant protection products.
This study aimed to determine the pathogenicity of strawberry Colletotrichum acutatum and evaluate different concentrations of five essential oils as potential bio-fungicides against strawberry anthracnose.

\section{Materials and methods}

The research was carried out at the Institute of Horticulture, Lithuanian Research Centre for Agriculture and Forestry in 2017-2020.

Extraction of essential oils (EO) and plant material. EO were obtained from naturally dried seeds of common thyme (Thymus vulgaris L.), common sage (Salvia officinalis L.), peppermint (Mentha piperita L.), hyssop (Hyssopus officinalis L.) and coriander (Coriandrum sativum L.). The EO were extracted by the Clevenger-type (Glassco, India) hydro-distillation for 2 hours.

Colletotrichum spp. isolates used in this research were collected in 2018 from the Institute of Horticulture, Lithuanian Research Centre for Agriculture and Forestry's experimental field from the infected strawberry (Fragaria $\times$ ananassa Duch.) cultivar 'Deluxe' fruits at BBCH 87 growth stage. The Colletotrichum sp. mycelium was maintained by sub-culturing on a potato-dextrose agar (PDA) at $25^{\circ} \mathrm{C}$ temperature for 7 days. This step was repeated twice to purify the culture, then single-spore isolates were extracted. Single spore Colletotrichum sp. isolates No. Fo5 $(44,61$ and 65) were stored on the PDA at $4^{\circ} \mathrm{C}$ temperature at the Laboratory of Plant Protection, Institute of Horticulture's isolate collection.

The isolates were initially identified by morphological attributes and confirmed by PCR as $C$. acutatum by ITS4 (TCCTCCGCTTATTGATATGC3) and CaInt2 (GGGGAAGCCTCTCGCGG) primers (Xie et al., 2010). The concentration of Colletotrichum sp. DNA was determined by measuring absorbance by a spectrometer NanoDrop 1000 (Thermo Fisher Scientific, USA). The PCR was performed in $25 \mu \mathrm{L}$ volume: $5 \mu \mathrm{L}$ $10 \times$ Tag buffer, $0.5 \mu \mathrm{L} 10 \mathrm{mM}$ dNTP Mix, $1.5 \mu \mathrm{L} 25 \mathrm{mM}$ $\mathrm{MgCl}_{2}, 0.5 \mu \mathrm{L}$ of each (CaInt2 and ITS4) primer, $1 \mu \mathrm{L}$ of DNA and $0.2 \mu \mathrm{L} 5 \mathrm{U}_{\mu} \mathrm{L}^{-1}$ Taq DNA polymerase (Thermo Fisher Scientific), and $15.8 \mu \mathrm{L}$ DNase/RNase-free water. The PCR was performed using a thermal cycler UNO 96 (VWR $\left.{ }^{\circledR}\right)$, and the conditions were 35 cycles, $1 \mathrm{~min}$ at $95^{\circ} \mathrm{C}, 30 \mathrm{~s}$ at $54^{\circ} \mathrm{C}$ and $1 \mathrm{~min}$ at $72^{\circ} \mathrm{C}$. PCR products were separated in $1.5 \%$ agarose gels with Midori Green Direct (Nippon Genetics Europe GmbH). The PCR reactions were repeated twice.

Colletotrichum acutatum pathogenicity experiments. To evaluate the pathogenicity of C.acutatum, the detached strawberry leaf assay was developed. Leaves were obtained from the Institute of Horticulture. Twelve strawberry cultivars: 'Sonata', 'Elkat', 'Rumba', 'Pandora', 'Syria', 'Elegance', 'Pegasus', 'Darselect', 'Asia', 'Furore', 'Deluxe' and 'Malvina', were chosen. The visually healthy strawberry leaves composed of three leaflets on a petiole without any visible disease symptoms were sterilized in a $70 \%$ ethanol solution for 3 min, rinsed 4-5 times with sterile distilled water and surface-dried for $5 \mathrm{~min}$ on sterile filter paper. The upper surface of leaves was wounded with a sterile needle and inoculated with $5 \mathrm{~mm}$ mycelial plugs (mycelial side down) in the centre of each multiple leaf.

The control treatment was not inoculated with the $C$. acutatum (control-1) to reject infection with other pathogens. A total of 16 leaves were used per treatment. The experiment was repeated four times, 
with four replicates. The plates were incubated at $25^{\circ} \mathrm{C}$ temperature in the dark. C. acutatum pathogenicity on strawberry cultivars was assessed at 14 days after inoculation (DAI). At the end of the experiment, the C. acutatum was reisolated from infected leaves and plated on PDA to recover the fungi. The pathogenicity ratings were based on a rating score (1-5): 1) no visible infection, 2) 1-5\% leaf area infected, 3) 5-10\% leaf area infected, 4) $20 \%$ leaf area infected and 5) $50 \%$ or more leaf area infected. The infected leaves were categorized (with some modifications) into four rating classes: 1) highly susceptible (3.5-5 rating), 2) susceptible (2.6-3.49 rating), 3) moderately resistant (1.6-2.59 rating) and 4) resistant (0-1.59 rating) (Prom et al., 2012).

Inhibitory effect of EO in vitro. To evaluate the inhibitory effect of different EO concentrations on C. acutatum, the $5 \mathrm{~mm}$ mycelial plugs of 7-day old fungus (No. Fo5) were cut and placed in the centre of PDA containing Petri plates. The 200, 400, 600, 800 and $1000 \mu 1 \mathrm{~L}^{-1}$ of pure EO were added to $45^{\circ} \mathrm{C}$ PDA medium. The plates were incubated at $25 \pm 2^{\circ} \mathrm{C}$ temperature in the dark. To compare growth without EO, the control treatment was not sprayed with EO (control-2). The experiments were repeated twice. The diameter $(\mathrm{cm})$ of $C$. acutatum colony (including the width of the disc) growth in two directions was measured after 2, 4 and 6 DAI. Calculation of the mean of colony growth diameter used for mycelial growth inhibition (MGI). The MGI was determined using the formula:

$$
\text { MGI }(\%)=\frac{(\mathrm{dc}-\mathrm{dt})}{\mathrm{dc}} \times 100,
$$

where $\mathrm{dc}$ is mycelium diameter of the pathogen colony in the control treatment in Petri dish, $\mathrm{cm}$; $\mathrm{dt}-$ mycelium diameter of the pathogen colony in the EO-treated Petri dish, cm (Idris et al., 2015; Šernaite et al., 2020).

EO inhibitory effect on detached strawberry leaves. The leaves of the strawberry cultivar 'Deluxe' were prepared as described in pathogenicity experiments. The sterilized rinsed and dried leaves were put on filter paper in a sterile tray, and $50 \mathrm{ml}$ of sterile distilled water was added. The upper surface of leaves was inoculated with $5 \mathrm{~mm}$ mycelial plugs (mycelial side down) in the centre of each multiple leaf. A total of 16 leaves were used per treatment; the experiment was repeated three times with four replicates. The leaves were sprayed with $5 \mathrm{ml}$ of 800 or $1000 \mu \mathrm{L} \mathrm{L}^{-1}$ of EO. To evaluate fungal growth without $\mathrm{EO}$, the control treatment was inoculated with $C$. acutatum but not sprayed with EO (control-3). The trays with detached leaves were incubated at $25^{\circ} \mathrm{C}$ temperature in the dark. The inhibitory effect of the treatments was evaluated by the infection area $(\mathrm{cm})$ and leaf area infected (\%) after 4 and 6 DAI. At the end of the experiment, the $C$. acutatum was reisolated from infected leaves and plated on PDA to recover the fungi.

The disease incidence was estimated as the number of symptomatic leaves over the total leaves by the rating score: 1) $0 \%$ - no visible infection, 2) $5 \%$, 3) $10 \%$, 4) $20 \%$ and 5) $50 \%$ or more area of leaf infected (Oliveira et al., 2019).

Disease severity index (DSI) of each inoculated plant leaf was assessed at 5 and 7 DAI by calculating the percentage of leaf area affected: 1) $0 \%-$ no visible infection, 2) $5 \%$, 3) $10 \%$, 4) $20 \%$ and 5) $50 \%$ or more area of leaf infected using the formula:

DSI $(\%)=$

$$
\frac{(0 \times \mathrm{P} 0)+(1 \times \mathrm{P} 1)+(2 \times \mathrm{P} 2)+(3 \times \mathrm{P} 3)+(4 \times \mathrm{P} 4)+(5 \times \mathrm{P} 5)}{\mathrm{N} \times \mathrm{G}} \times 100,
$$

where $\mathrm{P} 0$ to $\mathrm{P} 5$ is the total number of observed leaves in each corresponding scale, $\mathrm{N}$ - total number of leaves, $\mathrm{G}$ - number of maximum grades observed in the scale (Kone et al., 2017; Bajpai et al., 2019).

Statistical analysis. The experimental data were analysed using the analysis of variance (ANOVA) from the software SAS Enterprise Guide, version 7.1 (SAS Inc., USA). The standard error (SE) in the figures is marked as an error bar estimated for isolates growth rates. Duncan's multiple range test $(P<0.05)$ was used to determine differences among the treatments. Disease severity index expressed as mean \pm standard deviation.

\section{Results}

Colletotrichum acutatum pathogenicity. The detached leaf assay was developed to determine the pathogenicity of $C$. acutatum on various strawberry cultivars. The results revealed that C. acutatum isolate from strawberry was able to cause anthracnose to all cultivars and was pathogenic in this study. The clear C.acutatum necrotic (black) areas developed on inoculated leaves. The cultivar 'Deluxe' showed pathogenicity (3.75) and was attributed to the group of cultivars highly susceptible to anthracnose. Cultivars 'Malvina', 'Elkat', 'Pegasus', 'Furore' and 'Pandora' were attributed to the group of cultivars susceptible to anthracnose and had lower pathogenicity rating $(3.46,3.36,3.25,3.08$ and 2.83, respectively) ompared with the 'Deluxe'. Additionally, 'Syria', 'Darselect' and 'Sonata' were attributed to the group of moderately resistant cultivars. They were not significantly different from one another with 2.09, 2.07 and 2.0 pathogenicity rating, respectively. Compared with other cultivars, 'Asia', 'Elegance' and 'Rumba' had significantly lower disease incidence and showed the highest resistance. The least susceptible to $C$. acutatum was 'Rumba' (1.5) and 'Elegance' (1.5) (Figure 1).

Inhibitory effect of $E O$ in vitro. The differences of $C$. acutatum growth among the five EO were assessed after 2, 4 and 6 DAI (Figure 2). The results showed that Thymus vulgaris EO completely suppressed C. acutatum at concentrations $>200 \mu \mathrm{L} \mathrm{L}^{-1}$ : at $6 \mathrm{DAI}$, there were no visible fungal growth symptoms. The $C$. acutatum growth in the control-2 treatment at 2 DAI was $0.13 \mathrm{~cm}^{-1 a y}{ }^{-1}$ and at $6 \mathrm{DAI}-2.65 \mathrm{~cm} \mathrm{day}^{-1}$, as at all thymus concentrations growth was $0 \mathrm{~cm}^{\text {day }}{ }^{-1}$. T. vulgaris EO achieved the highest mycelial growth inhibition of $100 \%$ at all tested concentrations.

The data of our experiment indicate that the concentrations of Salvia officinalis EO against $C$. acutatum were not as effective as those of T. vulgaris. However, at the $800 \mu \mathrm{L} \mathrm{L}^{-1}$, slight mycelial growth inhibition $\left(0.06 \mathrm{~cm} \mathrm{day}^{-1}\right)$ can be seen. The results of 4 DAI show that the $200 \mu \mathrm{l} \mathrm{L}-1\left(0.54 \mathrm{~cm} \mathrm{day}^{-1}\right), 800 \mu \mathrm{L}^{-1}$ $\left(0.53 \mathrm{~cm} \mathrm{day}^{-1}\right)$ and $1000 \mu \mathrm{l} \mathrm{L}-1\left(0.53 \mathrm{~cm} \mathrm{day}^{-1}\right)$ had a slight effect on pathogen compared with the control-2 treatment. Besides, it was observed that the 400, 600 and $800 \mu \mathrm{L} \mathrm{L}^{-1}$ colony growth suppressed from 3.19 to 3.05 $\mathrm{cm}$ day $^{-1}$. However, at 6 DAI $S$. officinalis EO suppressed pathogen growth $\left(2.66 \mathrm{~cm} \mathrm{day}^{-1}\right)$ at the $1000 \mu \mathrm{L} \mathrm{L}^{-1}$ with the highest mycelial growth inhibition of $19.88 \%$, while in the control-2 treatment, the average colony growth of C. acutatum was $3.32 \mathrm{~cm}^{1}$ (Figure 2).

The data of Coriandrum sativum EO at 2 DAI demonstrated a slight mycelial growth inhibition from 0.15 to $0 \mathrm{~cm} \mathrm{day}^{-1}$; meanwhile, in the control-2 treatment, mycelium growth was $0.1 \mathrm{~cm}^{-1 a y^{-1}}$. At $4 \mathrm{DAI}$, the highest concentration of $C$. sativum EO showed the best result. 


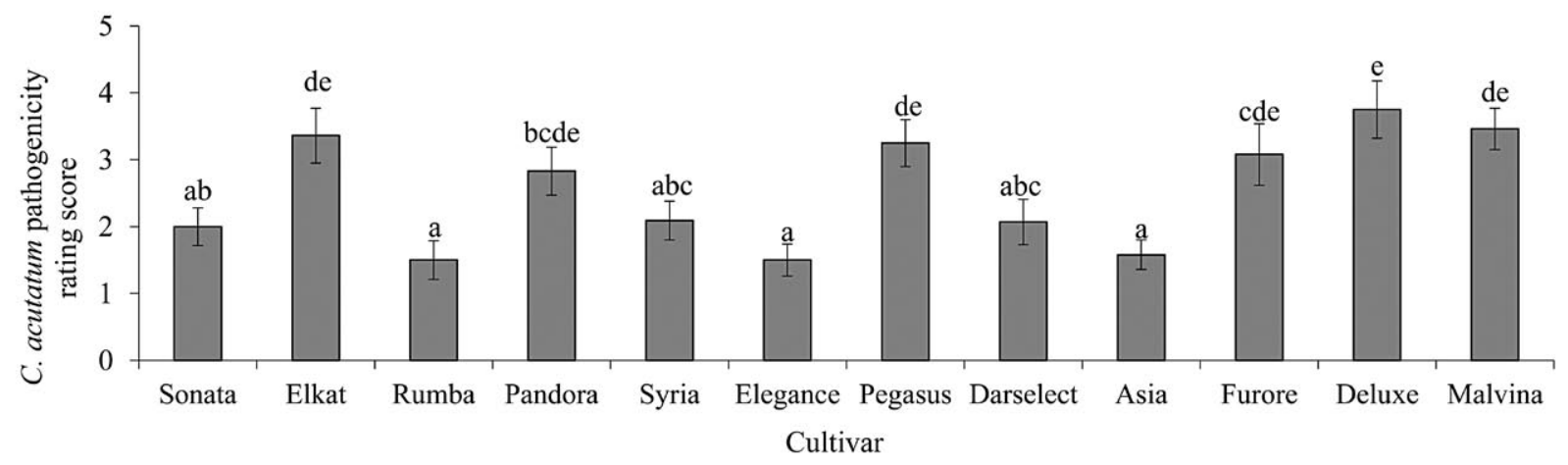

Note. Means followed by the same letter did not differ significantly $(P<0.05)$.

Figure 1. Pathogenicity of Colletotrichum acutatum to the strawberry cultivars at $14^{\text {th }}$ day after inoculation
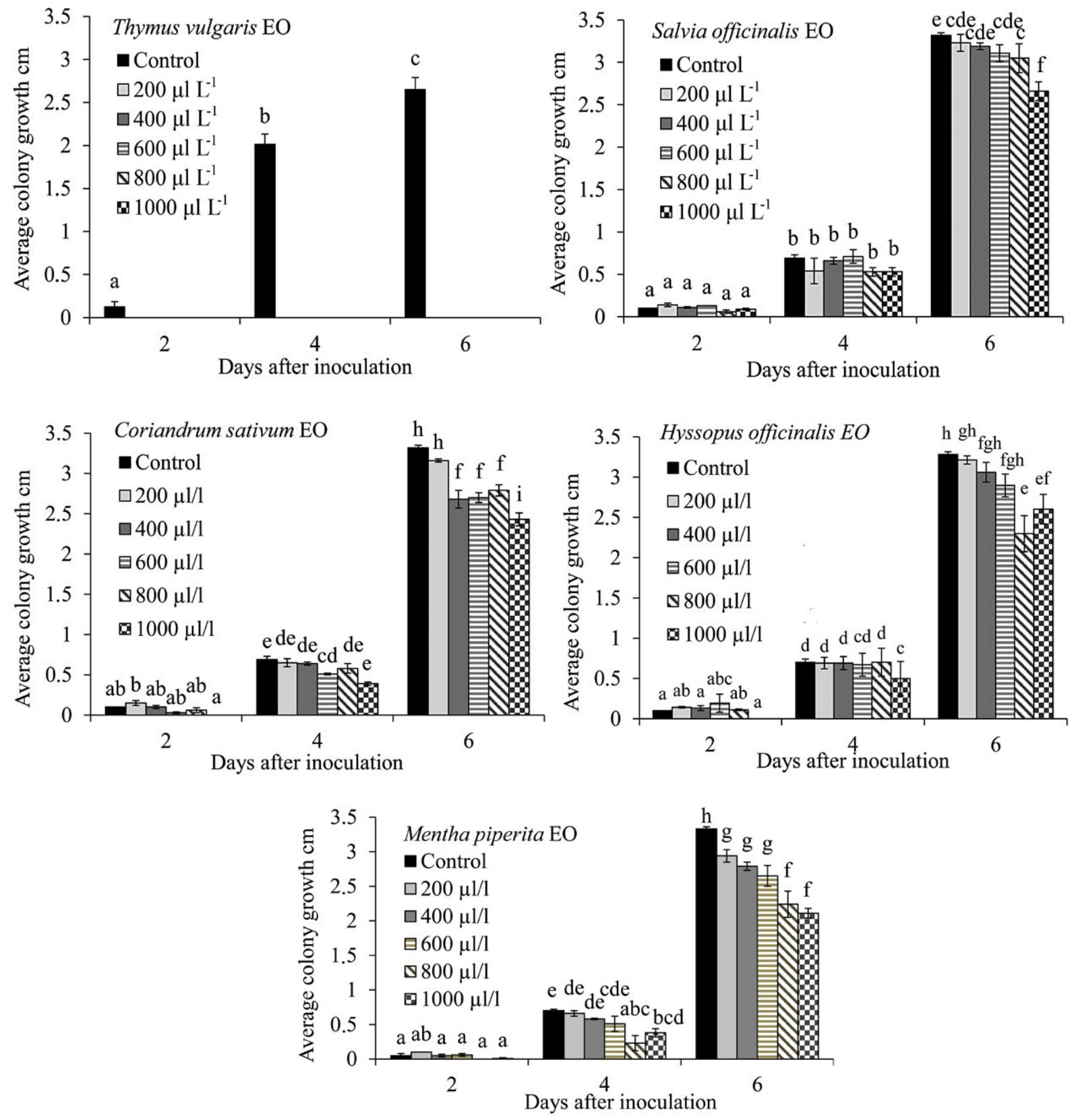

Note. Means followed by the same letter did not differ significantly $(P<0.05)$.

Figure 2. The inhibitory effect of five essential oils (EO) against Colletotrichum acutatum on strawberry after 2, 4 and 6 days after inoculation 
It reduced $C$. acutatum growth to $0.39 \mathrm{~cm}^{-1 a y}{ }^{-1}$ compared with the control-2 treatment $\left.\left(0.69 \mathrm{~cm}^{-1 a y}\right)^{-1}\right)$. According to the $C$. sativum data, there was observed a noticeable antifungal activity at 6 DAI compared EO concentrations with the control-2 treatment. The lowest colony growth was observed at $1000 \mu \mathrm{l} \mathrm{\textrm {L } ^ { - 1 }}$ : colony diameter was significantly lower $\left(2.43 \mathrm{~cm} \mathrm{day}^{-1}\right)$ than in the control-2 treatment $\left(3.32 \mathrm{~cm} \mathrm{day}^{-1}\right)$. The highest mycelial growth inhibition was $26.81 \%$, when the 400,600 and $800 \mu \mathrm{l}$ $\mathrm{L}^{-1}$ suppressed colony growth from 2.79 to $2.68 \mathrm{~cm} \mathrm{day}^{-1}$ (Figure 2)

Hyssopus officinalis EO at $1000 \mu \mathrm{l} \mathrm{L}^{-1}$ completely inhibited the growth of $C$. acutatum at 2 DAI. However, the growth of pathogen was $0.1 \mathrm{~cm} \mathrm{day}^{-1}$ in the control-2 treatment. The H. officinalis EO at 1000 $\mu 1 \mathrm{~L}^{-1}$ reduced colony growth $\left(0.49 \mathrm{~cm} \mathrm{day}^{-1}\right)$ compared with the control-2 treatment $\left(0.69 \mathrm{~cm} \mathrm{day}^{-1}\right)$ at 4 DAI. The $800 \mu \mathrm{L} \mathrm{L}^{-1}$ was most effective and showed the best result compared with the other concentrations at $6 \mathrm{DAI}$ $\left(2.26 \mathrm{~cm} \mathrm{day}^{-1}\right)$ and reached the highest mycelial growth inhibition rate of $30.03 \%$ (Figure 2).
The data of our experiment show that 4 DAI at the $800 \mu \mathrm{L} \mathrm{L}^{-1}$ of Mentha piperita EO colony growth decreased $\left(0.23 \mathrm{~cm} \mathrm{day}^{-1}\right)$ compared with the control2 treatment $\left(0.70 \mathrm{~cm} \mathrm{day}^{-1}\right)$. The lowest colony growth at 6 DAI was recorded at the highest concentration of $1000 \mu \mathrm{L} \mathrm{L}^{-1}\left(2.11 \mathrm{~cm} \mathrm{day}^{-1}\right)$ compared with the control2 treatment $\left(3.33 \mathrm{~cm} \mathrm{day}^{-1}\right)$. The highest concentration demonstrated $36.64 \%$ MGI. M. piperita EO had better antifungal activity than $S$. officinalis, $H$. officinalis and C. sativum EO 6 DAI against $C$. acutatum (Figure 2).

EO inhibitory effect on detached strawberry leaves. Evaluation of the highest efficient concentrations (800 and $1000 \mu \mathrm{L} \mathrm{L}^{-1}$ ) of EO on detached strawberry leaves is presented in Figure 3.

The results of the experiment revealed that the highest disease incidence score was recorded at $6 \mathrm{DAI}$ of the treatment with $800 \mu \mathrm{L} \mathrm{L}^{-1}$ of the C. sativum EO. However, the results of $1000 \mu \mathrm{L}^{-1}$ were significantly different. C. sativum EO reduced C. acutatum growth at $4 \mathrm{DAI}$, and disease incidence rating was equal compared with the control-3 treatment at 6 DAI. T. vulgaris EO

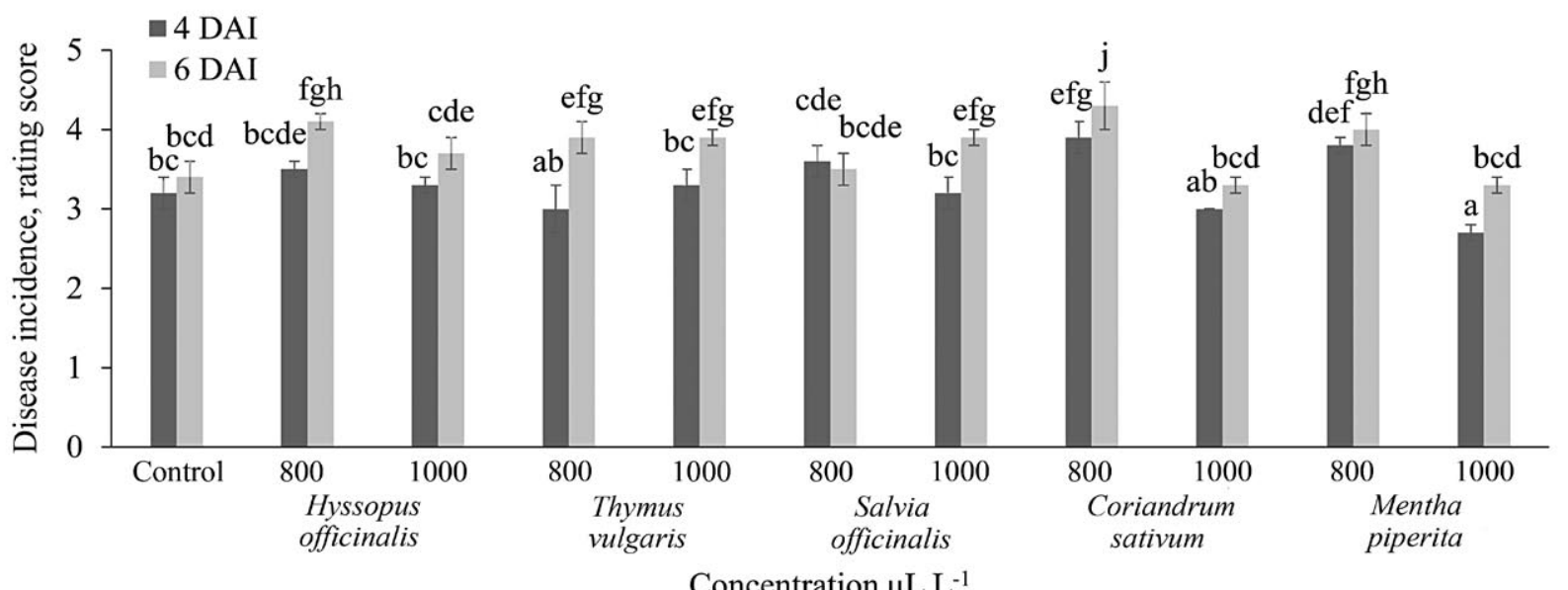

Concentration $\mu \mathrm{L} \mathrm{L}^{-1}$

Note. Means followed by the same letter did not differ significantly $(P<0.05)$.

Figure 3. The inhibitory effect of essential oils (EO) against Colletotrichum acutatum on detached strawberry leaves at 4 and 6 days after inoculation (DAI)

showed inhibition of $C$. acutatum at $800 \mu \mathrm{L}^{-1}$ at $4 \mathrm{DAI}$. T. vulgaris $\mathrm{EO}$ was found to be the most effective against strawberry anthracnose and gave the highest inhibition of C. acutatum growth. M. piperita $\mathrm{EO}$ at $1000 \mu 1 \mathrm{~L}^{-1}$ reduced disease severity compared with control-3 treatment and other concentrations. However, in H. officinalis EO treatment at $800 \mu \mathrm{L} \mathrm{L}^{-1}$, the suppression of C. acutatum was not efficient (Figure 3).
The disease severity index ranged from 66.67 to 100 at 4 DAI. The lowest disease severity index value was observed of $M$. piperita EO at $800 \mu \mathrm{L}^{-1}$ at $4 \mathrm{DAI}$. Reduction of disease severity by $M$. piperita EO was significantly higher than control-3 and other treatments at 4 DAI (Table).

Table. Percentage of disease severity index on strawberry cultivar 'Deluxe' at 4 and 6 days after inoculation (DAI)

\begin{tabular}{|c|c|c|c|c|c|c|c|c|c|c|c|}
\hline \multirow{2}{*}{$\begin{array}{c}\text { Colletotrichum } \\
\text { acutatum disease } \\
\text { severity index } \%\end{array}$} & \multirow{2}{*}{$\begin{array}{c}\text { Control- } \\
3 \\
-\end{array}$} & \multicolumn{2}{|c|}{$\begin{array}{l}\text { Hyssopus } \\
\text { officinalis }\end{array}$} & \multicolumn{2}{|c|}{$\begin{array}{l}\text { Thymus } \\
\text { vulgaris }\end{array}$} & \multicolumn{2}{|c|}{$\begin{array}{c}\text { Salvia } \\
\text { officinalis }\end{array}$} & \multicolumn{2}{|c|}{$\begin{array}{l}\text { Coriandrum } \\
\text { sativum }\end{array}$} & \multicolumn{2}{|c|}{$\begin{array}{l}\text { Mentha } \\
\text { piperita }\end{array}$} \\
\hline & & 800 & 1000 & 800 & 1000 & 800 & 1000 & 800 & 1000 & 800 & 1000 \\
\hline 4 DAI & $\begin{aligned} & 79.2 \\
\pm & 0.2 \mathrm{~g}\end{aligned}$ & $\begin{array}{c}87.5 \pm \\
0.11\end{array}$ & $\begin{array}{c}83.3 \pm \\
0.1 \mathrm{j}\end{array}$ & $\begin{array}{c}75.0 \pm \\
0.3 \mathrm{e}\end{array}$ & $\begin{array}{c}81.9 \pm \\
0.2 \mathrm{c}\end{array}$ & $\begin{array}{c}90.3 \pm \\
0.2 \mathrm{n}\end{array}$ & $\begin{array}{c}81.9 \pm \\
0.1 \mathrm{c}\end{array}$ & $\begin{array}{c}78.9 \pm \\
0.2 \mathrm{f}\end{array}$ & $\begin{array}{c}100 \pm \\
0 \mathrm{r}\end{array}$ & $\begin{array}{c}94.4 \pm \\
0.1 \mathrm{p}\end{array}$ & $\begin{array}{c}66.7 \pm \\
0.1 \mathrm{a}\end{array}$ \\
\hline 6 DAI & $\begin{array}{c}67.8 \\
\pm 0.2 \mathrm{~d}\end{array}$ & $\begin{array}{c}82.2 \pm \\
0.1 \mathrm{i}\end{array}$ & $\begin{array}{c}91.7 \pm \\
0.2 \mathrm{o}\end{array}$ & $\begin{array}{c}77.8 \pm \\
0.3 \mathrm{~b}\end{array}$ & $\begin{array}{c}97.2 \pm \\
0.1 \mathrm{q}\end{array}$ & $\begin{array}{l}88.9 \pm \\
0.2 \mathrm{~m}\end{array}$ & $\begin{array}{c}77.8 \pm \\
0.1 \mathrm{~b}\end{array}$ & $\begin{array}{c}85.6 \pm \\
0.3 \mathrm{k}\end{array}$ & $\begin{array}{c}81.9 \pm \\
0.1 \mathrm{c}\end{array}$ & $\begin{array}{c}80.0 \pm \\
0.2 \mathrm{~h}\end{array}$ & $\begin{array}{c}81.9 \pm \\
0.2 \mathrm{c}\end{array}$ \\
\hline
\end{tabular}

Note. Means followed by the same letter did not differ significantly $(P<0.05)$; results expressed as mean \pm standard deviation. 


\section{Discussion}

According to Zhang et al. (2016), no strawberry cultivar has been found to show complete resistance to Colletotrichum spp. The pathogenicity tests showed significant differences among strawberry cultivars. Pathogenicity tests in the cultivar 'Deluxe' showed the highest pathogenicity while cultivars 'Rumba' and 'Elegance' had resistance to C. acutatum. The data of our experiment revealed that various cultivars are differently susceptible to $C$. acutatum. Wagner and Hetman (2016) reported that 'Florence' was more susceptible to C. acutatum than other cultivars, e.g., 'Darselect'. Leandro et al. (2001) reported that C. acutatum causing symptomless infection of strawberry is a source of inoculum for fruit infections. Garrido et al. (2008) found out that $C$. acutatum was more pathogenic than C.gloeosporioides to cultivars 'Camarosa' and 'Ventana'. El Kaissoumi et al. (2018) reported that there are significant differences in disease severity between cultivars. The most susceptible to Colletotrichum spp. was 'Fortuna'. Besides, due to C. gloeosporioides infection, pathogen develops brown spots and irregular blotches on strawberries. However, due to the Colletotrichum spp. tissues colonization, their pathogenicity and survival on different plant parts of various strawberry cultivars showed differences (El Kaissoumi et al., 2018). Seijo et al. (2008) found out different resistance levels in various strawberry cultivars.

The knowledge about various cultivars could help integrated plant protection. The effective EO as potential bio-fungicides could differently suppress Colletotrichum spp. on various cultivars. Pathogenicity results showed that $C$. acutatum is capable of infecting strawberry, and pathogenic variation could exist.

Results of our experiment indicate significant differences between all evaluated EO concentrations. Higher concentrations of EO show the inhibitory effect on strawberry pathogen $C$. acutatum.

Sarkhosh et al. (2018) found that T. vulgaris EO completely inhibited Colletotrichum spp. mycelial growth at a concentration of $100 \mu \mathrm{L}^{-1}$ in avocado, mango and papaya fruits. According to another study by Sarkhosh et al. (2017), T. vulgaris EO concentration of $125 \mu \mathrm{L} \mathrm{L}^{-1}$ completely inhibited Colletotrichum spp. in papaya fruits. Rodrigues et al. (2018) reported that different $\mathrm{EO}$ concentrations are suitable for $C$. musae control. Amini et al. (2012) observed antifungal activity of T. vulgaris EO against Botrytis cinerea, Aspergillus spp., Rhizoctonia solani and other pathogens. Foltinová et al. (2017) documented that T. vulgaris EO $100 \%$ inhibited the growth of tested isolates of Aspergillus flavus. The data of our experiment agree with those obtained by other researchers suggesting that $T$. vulgaris EO could be an effective biological agent to control Colletotrichum sp. until 6 DAI.

According to Scariot et al. (2016), S. officinalis EO has fungicidal activity against Alternaria spp. and Phakopsora pachyrhizi in beans. The data of our experiment indicate that $S$. officinalis EO did not demonstrate the high tendency of $C$. acutatum inhibition on strawberry. In comparison, the efficiency of $S$. officinalis and $C$. sativum EO against $C$. acutatum pathogen was very similar. Aćimović et al. (2016) reported that C. sativum EO could inhibit colony growth by $90 \%$. However, the highest concentrations of EO should be used. Mandal and Mandal (2015) reported that $C$. sativum EO at the
1500-2000 $\mu \mathrm{g} \mathrm{mL} \mathrm{mL}^{-1}$ could be useful against Alternaria spp., Fusarium spp. and other pathogens.

The data of our experiment indicate that H. officinalis EO had a better antifungal effect than $S$. officinalis and C. sativum EO. Letessier et al. (2001) observed that $H$. officinalis EO at $0.4 \%$ concentration completely inhibited mycelial growth of pathogenic fungi Pyrenophora avenae and Pyricularia oryzae.

$M$. piperita EO had better antifungal activity against $C$. acutatum than $S$. officinalis, $H$. officinalis and C. sativum EO at 6 DAI. The literature review has shown that $M$. piperita EO can be used as a biological control product against strawberry anthracnose. Results show that M. piperita $\mathrm{EO}$ at a concentration of $1500 \mu \mathrm{L}^{-1}$ gave complete mycelial growth inhibition (Sarkhosh et al., 2018). Based on the results of our experiment, it can be assumed that higher concentrations of M. piperita EO could effectively inhibit C. acutatum. Moghaddam et al. (2012) observed that $M$. piperita EO up to $1600 \mu 1 \mathrm{~L}^{-1}$ could control Fusarium oxysporum f. sp. ciceris, Macrophomina phaseolina and Dreschlera spicifera.

The micelial growth inhibition of $C$. acutatum by $T$. vulgaris EO was evident; it has the potential to control strawberry anthracnose and could be considered for use as a biocontrol agent against fungal pathogens. However, further research is needed to evaluate higher EO concentrations. The T. vulgaris EO inhibitory effect was evaluated on the detached leaves of strawberry cultivar 'Deluxe'.

In this study, five EO showed differing efficacy on $C$. acutatum. T. vulgaris EO was the most effective at the lowest concentration in in vitro experiments. However, in the assay of detached strawberry leaves, even at high concentrations $T$. vulgaris EO gave a slight disease severity reduction compared with the control-3 treatment at 4 DAI. M. piperita $\mathrm{EO}$ at higher concentration reduced disease severity compared with the control-3 and other EO treatments at 4 and 6 DAI. Oliveira et al. (2019) suggest that higher concentrations of EO are usually required in the experiments in vivo.

\section{Conclusions}

1. According to the pathogenicity screening, 'Deluxe' was the most susceptible cultivar to strawberry anthracnose, while 'Rumba' and 'Elegance' exhibited resistance.

2. The growth of Colletotrichum acutatum was reduced with the tested essential oils (EO) applied at the highest concentrations in vitro.

3. Thymus vulgaris EO caused $100 \%$ micelial growth inhibition of C. acutatum at $200 \mu \mathrm{L} \mathrm{L}^{-1}$ and higher concentrations in vitro.

4. Essential oils inhibited the mycelial growth of $C$. acutatum in vitro; however, the assay of detached strawberry leaves showed that the efficacy of EO is not sufficient.

As a result, further investigation, including higher EO concentrations, is needed.

\section{Acknowledgements}

This research was partly funded by the World Federation of Scientists, National Scholarship Programme.

Received 23032020 Accepted 01022021 


\section{References}

Aćimović M. G., Grahovac M. S., Stanković J. M., Cvetković M. T., Maširević S. N. 2016. Essential oil composition of different coriander (Coriandrum sativum L.) accessions and their influence on mycelial growth of Colletotrichum spp. Acta Scientiarum Polonorum Hortorum Cultus, 15 (4): 35-44. https://open. uns.ac.rs/handle/123456789/5067

Aguado A., Pastrana A. M., de los Santos B., Romero F., Sánchez M.C., Capote N. 2014. Efficiency of natural products in the control of Colletotrichum acutatum monitored by realtime PCR. Acta Horticulturae, 1049: 329-334. https://doi.org/10.17660/ActaHortic.2014.1049.44

Amini M., Safaie N., Salmani M. J., Shams-Bakhsh M. 2012. Antifungal activity of three medicinal plant essential oils against some phytopathogenic fungi. Trakia Journal of Sciences, $10(1): 1-8$ http://dx.doi.org/10.14715/cmb/2017.64.15.3

Avila-Quezada G. D., Esquivel J. F., Silva-Rojas H. V., LeyvaMir S. G., Garcia-Avila C. de J., Noriega-Orozco L., RivasValencia P., Ojeda-Barrios D., Melgoza-Castillo A. 2018. Emerging plant diseases under a changing climate scenario: threats to our global food supply. Emirates Journal of Food and Agriculture, 30 (6): 443: 450.

Bajpai S., Shukla P. S., Asiedu S., Pruski K., Prithiviraj B. 2019. A biostimulant preparation brown seaweed Ascophyllum nodosum suppresses powdery mildew of strawberry. The Plant Pathology Journal. 35 (5): 406-416.

https://doi.org/10.5423/PPJ.OA.03.2019.0066

Çetin B., Çakmakçi S., Çakmakçi R. 2011. The investigation of antimicrobial activity of thyme and oregano essential oils. Turkish Journal of Agriculture and Forestry, 35 (2): 145-154. https://doi.org/10.39

Debode J., Van Hemelrijck W., Xu X.-M., Maes M., Creemers P., Heungens K. 2015. Latent entry and spread of Colletotrichum acutatum (species complex) in strawberry fields. Plant Pathologv. 64 (2): 385-395. https://doi.org/10.1111/ppa.12247

Desam N. R., Al-Rajab A. J., Sharma M., Mylabathula M. M., Gowkanapalli R. R., Albratty M. 2017. Chemical constituents, in vitro antibacterial and antifungal activity of Mentha $\times$ piperita L. (peppermint) essential oils. Journal of King Saud University - Science, 31 (4): 528-533. https://doi.org/10.1016/j.jksus.2017.07.013

Duduk N., Markovic T., Vasic M., Duduk B., Vico I., Obradovic A. 2015. Antifungal activity of three essential oils against Colletotrichum acutatum, the causal agent of strawberry anthracnose. Journal of Essential Oil Bearing Plants. 18 (3): 529-537. https://doi.org/10.1080/0972060X.2015.1004120

El Kaissoumi H., Mouden N., Chliyeh M., Benkirane R., Ouazzani Touhami A., Douira A. 2018. Comparative pathogenicity of Colletotrichum spp. against different varieties of strawberry plants (Fragaria ananassa) widely grown in Morocco. Acta Phytopathologica et Entomologica Hungarica. 53 (2): 1-20. https://doi.org/10.1556/038.53.2018.008

Foltinová D., Tančinová D., Císarová M. 2017. Influence of essential oils on the growth of Aspergillus flavus. Potravinarstvo. Slovak Journal of Food Sciences, 11 (1): 322-331. https://doi.org/10.5219/725

Freeman S., Horowitz S., Sharon A. 2001. Pathogenic and nonpathogenic life styles in Colletotrichum acutatum from strawberry and other plants. Phytopathology, 91 (10): 986-992. https://doi.org/10.1094/PHYTO.2001.91.10.986

Garrido C., Carbú M., Fernández-Acero F. J., Budge G., Vallejo I., Colyer A., Cantoral J. M. 2008. Isolation and pathogenicity of Colletotrichum spp. causing anthracnose of strawberry in south west Spain. European Journal of Plant Pathologv. 120: 409-415.

https://doi.org/10.1007/s10658-007-9224-7

Girish K., Fathima S. K. 2019. Antifungal activity of essential oils on Phomopsis azadirachtae causing die-back of neem. Journal of Biopesticides, 12 (1): 45-50.
Idris F. M., Ibrahim A. M., Forsido S. V. 2015. Essential oils to control Colletotrichum musae in vitro and in vivo on banana fruits. American-Eurasian Journal of Agricultural and Environmental Sciences, 15 (3): 291-302.

Kone N., Asare-Bediako E., Silue S., Kone D., Koita O., Menzel W., Winter S. 2017. Influence of planting date on incidence and severity of viral disease on cucurbits under field condition. Annals of Agricultural Sciences, 62 (1): 99-104. https://doi.org/10.1016/j.aoas.2017.05.005

Kumar A., Kudachikar V. B. 2018. Antifungal properties of essential oils against anthracnose disease: a critical appraisal. Journal of Plant Diseases and Protection. 125: 133-144. https://doi.org/10.1007/s41348-017-0128-2

Laribi B., Kouki K., M’Hamdi M., Bettaieb T. 2015. Coriander (Coriandrum sativum L.) and its bioactive constituents. Fitoterapia, 103: 9-26. https://doi.org/10.1016/j.fitote.2015.03.012

Leandro L. F. S., Gleason M. L., Nutter F. W. Jr., Wegulo S. N., Dixon P. M. 2001. Germination and sporulation of Colletotrichum acutatum on symptomless strawberry leaves. Phytopathology, 91 (7): 659-664. https://doi.org/10.1094/PHYTO.2001.91.7.659

Letessier M. P., Svoboda K. P., Walters D. R. 2001. Antifungal activity of the essential oil of hyssop (Hyssopus officinalis). Journal of Phytonathology, 149 (11-12): 673-678 https://doi.org/10.1046/j.1439-0434.2001.00692.x

MacKenzie S. J., Peres N. A., Barquero M. P., Arauz L. F., Timmer L. W. 2009. Host range and genetic relatedness of Colletotrichum acutatum isolates from fruit crops and leatherleaf fern in Florida. Phytonathology, 99 (5): 620-631. https://doi.org/10.1094/PHYTO-99-5-0620

Mandal S., Mandal M. 2015. Coriander (Coriandrum sativum L.) essential oil: chemistry and biological activity. Asian Pacific Journal of Tronical Biomedicine. 5 (6): 421-428. https://doi.org/10.1016/j.apjtb.2015.04.001

Miller-Butler M. A., Smith B. J., Babiker E. M., Kreiser B. R., Blythe E. K. 2018. Comparison of whole plant and detached leaf screening techniques for identifying anthracnose resistance in strawberry plants. Plant Disease, 102 (11): 2112-2119. https://doi.org/10.1094/PDIS-08-17-1138-RE

Miller-Butler M. A., Smith B. J., Curry K. J., Blythe E. K. 2019. Evaluation of detached strawberry leaves for anthracnose disease severity using image analysis and visual ratings. HortScience. 54 (12): 2111-2117. https://doi.org/10.21273/HORTSCI14321-19

Moghaddam M., Pourbaige M., Tabar H. K., Farhadi N., Hosseini S. M. A. 2012. Composition and antifungal activity of peppermint (Mentha piperita) essential oil from Iran. Journal of Essential Oil Bearing Plants, 16 (4): $506-512$ https://doi.org/10.1080/0972060X.2013.813265

Moral J., Jurado-Bello J., Sánchez M. I., de Oliveira R., Trapero A. 2012. Effect of temperature, wetness duration, and planting density on olive anthracnose caused by Colletotrichum snn. Phytonathologv. 102 (10): 974-981. https://doi.org/10.1094/PHYTO-12-11-0343

Oliveira J., Gloria E. M., Parisi M. C. M., Baggio J. S., Silva P. P. M., Ambrosio C. M. S., Spoto M. H. F. 2019. Antifungal activity of essential oils associated with carboxymethylcellulose against Colletotrichum acutatum in strawberries. Scientia Horticulturae, 243: 261-267. https://doi.org/10.1016/j.scienta.2018.08.032

Parikka P., Lemmetty A., Sundelin T., Strømeng G. M., Stensvand A. 2016. Survival of Colletotrichum acutatum in plant residue. Acta Horticulturae. 1117: 177-180. https://doi.org/10.17660/ActaHortic.2016.1117.28

Peres N. A., Timmer L. W., Adaskaveg J. E., Correll J. C. 2005. Lifestyles of Colletotrichum acutatum. Plant Disease, 89 (8): 784-796. https://doi.org/10.1094/PD-89-0784

Prom L. K., Erpelding J., Perumal R., Isakeit T., Cuevas H. 2012. Response of sorghum accessions from four African countries against Colletotrichum sublineolum, causal agent of sorghum anthracnose. American Journal of Plant Sciences. 3 (1): 125-129. https://doi.org/10.4236/ajps.2012.31014 
Rodrigues M. L. M., Mizobutsi E. H., Fagundes I. R. F. F., Fernandes M. B., Mizobutsi G. P., Ribeiro R. C. F., dos Reis S. T., Pinheiro J. M. S., Prates P. J. L., Lage G. G. A. 2018. Essential oils in the control of anthracnose on 'Prata Ana' banana. Journal of Agricultural Science, 10 (9): 116-124. https://doi.org/10.5539/jas.v10n9p116

Sarkhosh A., Schaffer B., Vargas A. I., Palmateer A. J., Lopez P., Soleymanic A., Farzanehd M. 2017. Antifungal activity of five plant-extracted essential oils against anthracnose in papaya fruit. Biological Agriculture and Horticulture, 34 (1): 18-26. https://doi.org/10.1080/01448765.2017.1358667

Sarkhosh A., Schaffer B., Vargas A. I., Palmateer A. J., Lopez P., Soleymanic A. 2018. In vitro evaluation of eight plant essential oils for controlling Colletotrichum, Botryosphaeria, Fusarium and Phytophthora fruit rots of avocado, mango and nanava. Plant Protection Science, 54 (3): 153-162. https://doi.org/10.17221/49/2017-PPS

Scariot M. A., Wilson Reichert Jr. F., Radünz L. L., Barro J. P., Mossi A. J. 2016. Salvia officinalis essential oil in bean weevil control. Pesquisa Agronecuária Tronical, 46 (2): 177-182. https://doi.org/10.1590/1983-40632016v4640034

Seijo T. E., Chandler C. K., Mertely J. C., Moyer C., Peres N. A. 2008. Resistance of strawberry cultivars and advanced selections to anthracnose and botrytis fruit rots. Proceedings of the Florida State Horticultural Society, 121: 246-248.

Singh G., Maurya S., de Lampasona M. P., Catalan C. A. N. 2006. Studies on essential oils, Part 41. Chemical composition, antifungal, antioxidant and sprout suppressant activities of coriander (Coriandrum sativum) essential oil and its oleoresin. Flavour and Fragrance Journal, 21 (3): 472-479. https://doi.org/10.1002/ffj. 1608

Sreenivasaprasad S., Talhinhas P. 2005. Genotypic and phenotypic diversity in Colletotrichum acutatum, a cosmopolitan pathogen causing anthracnose on a wide range of hosts. Molecular Plant Pathology, 6 (4): 361-378. https://doi.org/10.1111/j.1364-3703.2005.00291.x

Starović M., Ristić D., Pavlović S., Ristić M., Stevanović M., AlJuhaimi F., Naydun S., Özcan M. M. 2016. Antifungal activities of different essential oils against anise seeds mycopopulations. Journal of Food Safety and Food Quality, 67 (3): 72-78. http://plantarum.izbis.bg.ac.rs/ handle/123456789/441

Šernaitė L., Valiuškaitė A., Rasiukevičiūtè N., Dambrauskienė E., Viškelis P. 2020. Effectiveness of mixtures and individual plant extracts and essential oils for biocontrol of Botrytis cinerea. Zemdirbvste-Agriculture. 107 (2): 147-152. https://doi.org/10.13080/z-a.2020.107.019

Wagner A., Hetman B. 2016. Susceptibility of strawberry cultivars to Colletotrichum acutatum J. H. Simmonds. Acta Scientiarum Polonorum. Hortorum Cultus, 15 (6): 209-219.

Xie L., Zhang J., Wan Y., Hu D. 2010. Identification of Colletotrichum spp. isolated from strawberry in Zhejiang Province and Shanghai City, China. Journal of Zhejiang University, Science B: Biomedicine and Biotechnology, 11 (1): 61-70. https://doi.org/10.1631/jzus.B0900174

Yilar M., Kadioglu I., Telci I. 2018. Chemical composition and antifungal activity of Salvia officinalis (L.), S. cryptantha (Montbret et Aucher ex Benth.), S. tomentosa (Mill.) plant essential oils and extracts. Fresenius Environmental Bulletin, 27 (3): 1695-1706. https://hdl.handle. net/20.500.12513/4008

Zhang Q., Zhang L., Song L., Duan K., Li N., Wang Y., Gao H. 2016. The different interactions of Colletotrichum gloeosporioides with two strawberry varieties and the involvement of salicylic acid. Horticulture Research, 3: 16007. https://doi.org/10.1038/hortres.2016.7

\title{
Colletotrichum acutatum patogeniškumas ir biokontrolè ivairių veislių braškėms panaudojus eterinius aliejus
}

\author{
A. Morkeliūnè, N. Rasiukevičiūtè, A. Valiuškaitè
}

Lietuvos agrarinių ir miškų mokslų centras

\section{Santrauka}

Colletotrichum spp. yra svarbus braškių patogenas, galintis iki $80 \%$ sumažinti jų derlių. Dėl pakitusių agrometeorologinių sąlygų stebimas jo plitimas vėsesnio klimato šalyse. Kaip viena iš ekologiškų augalų patogenų kontrolès priemonių gali būti panaudoti eteriniai aliejai. Jie turi antibakterinių ir antigrybinių savybių; mažas toksiškumas ir biologinè sklaida aplinkoje juos leidžia naudoti augalų apsaugai nuo patogenų vietoj cheminių produktų.

Tyrimo metu siekta nustatyti braškių $C$. acutatum patogeniškumą ir ịvertinti penkių koncentracijų eterinius aliejus kaip galimus biofungicidus apsaugai nuo braškių antraknozės. C. acutatum patogeniškumo tyrimas atliktas ant nuo augalo atskirtų braškių lapų. Eterinių aliejų slopinantis poveikis įvertintas panaudojus 200, 400, 600, 800 ir $1000 \mu \mathrm{L} \mathrm{L}^{-1}$ koncentracijas in vitro ir 800 bei $1000 \mu \mathrm{L} \mathrm{L}^{-1}$ koncentracijas ant atskirtų braškių lapų. Antraknozei jautriausios buvo veislès 'Deluxe' braškės, o veislių 'Rumba' ir 'Elegance' braškès buvo atsparios. Tyrimo duomenimis, Mentha piperita eterinis aliejus (EA) pasižymejjo antigrybiniu poveikiu nuo C. acutatum, o Salvia officinalis EA neturejo jokio poveikio. Coriandrum sativum ir Hyssopus officinalis EA nežymiai slopino C. acutatum augimą. Thymus vulgaris EA in vitro tyrimo rezultatai atskleidè, kad tai gali būti veiksmingas braškių antraknozès biokontrolès agentas. T. vulgaris EA slopino C. acutatum micelio augimą in vitro, tačiau rezultatai ant atskirtų braškių lapų parodè, kad eterinių aliejų veiksmingumas buvo nepakankamas, todèl reikia tolesnių tyrimų.

Reikšminiai žodžiai: antigrybinis poveikis, blakinè kalendra, pipirmėte, vaistinis čiobrelis, vaistinis isopas, vaistinis šalavijas. 